\title{
Does Regional Autonomy Improve Local Public Services in More Diverse Regions?
}

\author{
Andrea Filippetti
}

This chapter examines the relationship between diversity, access to local public services and regional autonomy. It starts from a common belief that the presence of marked diversity in communities might impair the functioning of the welfare state. By looking at the satisfaction of citizens about local public services - school, health and local policy - in European regions, this chapter shows empirically that citizens tend to be less satisfied about public services in regions characterised by higher diversity. This can question the access to public services in heterogenous places. In a second step, we examine whether regional autonomy can mediate this problem by relying on fiscal federalism theory, which argues that in the presence of heterogeneity across jurisdictions, a decentralised management of public services is more efficient. We find that in diverse regions, regional autonomy improves the satisfaction of citizens concerning local public services. This suggests that regional autonomy can represent a possible solution to guarantee equal access to public services in heterogenous societies.

The next 'Europe of regions' will profoundly differ from the present one. In fact, one of the most pressing challenges in many European countries stems from a relentless increase in the heterogeneity of population. This is the result of intra-European Union (EU) mobility, and migration from outside the EU. While some countries - such as France and the United Kingdom - have already experienced such differences within their borders due to their relationships with former colonies, and others - such as Germany - have experienced more recent flows related to job opportunities, for most European countries and regions this will be a new phenomenon for public policy to cope with. ${ }^{1}$

1 Gregory B. Christainsen, "Biology, Immigration, and Public Policy," Kyklos 65, no. 2 (2012), 164-178; James Dennison and Andrew Geddes, "Brexit and the Perils of 'Europeanised' Migration," Journal of European Public Policy 25, no. 8 (2018), 1-17. 
One of the consequences of this process is the increasing pressure on the welfare states, particularly regarding the provision of local basic services, such as health, public housing, local policy and education. Alesina and Glaeser argue that 'one natural implication of our conclusion that fractionalization reduces redistribution is that if Europe becomes more heterogeneous due to immigration, ethnic divisions will be used to challenge the generous welfare state. ${ }^{2}$ As such, they raise a concern about a trade-off between a generous immigration policy and a generous welfare state. This is crucial for the European Union, since mobility of people represents one of its cornerstones. In the words of Britain's ambassador to Berlin, Sir Sebastian Wood, 'it is freedom of movement for workers, and not freedom of movement for 'welfare shopping". 3 This problem has been restated recently in a commentary by Branko Milanovic, a leading expert on global inequality, who argues that welfare states attract a lot of unskilled migrants. ${ }^{4}$

Since in most cases local public services are either provided or managed at the regional or local level, the regions - and the regional governments are expected to play an increasing role in managing this process. This issue has been addressed at the subnational level by research limited to the United States, precisely because public spending at the state level is of a different kind than at the country level. ${ }^{5}$ This chapter aims to inform this debate by looking at the issue of diversity and the provision of local public services in European regions.

Several studies have enquired whether the presence of a highly heterogeneous population reduces the quality of local public policies. The answer is positive in most cases, ${ }^{6}$ although much of the research has addressed ethnic diversity and has been carried out either in the Unites States or in developing countries, in which these ethnic differences are considerable. ${ }^{7}$

Alberto Alesina and Edward Ludwig Glaeser, Fighting Poverty in the US and Europe: A World of Difference (Oxford: Oxford University Press, 2004), 11.

3 Tom Barfield, "UK asks for German help to stop 'welfare shopping,", The Local, 18 Febuary 2016, https:/www.thelocal.de/2016o218/uk-asks-german-help-to-stop-welfare-shopping. Branko Milanovic, "Migration Vs. the Welfare State?," the Globalist, 16 May 2017, https:// www.theglobalist.com/migration-vs-the-welfare-state/.

David M. Cutler, Douglas W. Elmendorf and Richard J. Zeckhauser, "Demographic Characteristics and the Public Bundle," National Bureau of Economic Research NBER Working Paper, no. 4283 (February 1993), 1-18, https://doi.org/10.3386/w4283,.

6 For a recent review see Holger Stichnoth and Karine van der Straeten, "Ethnic Diversity, Public Spending, and Individual Support for The Welfare State: A Review of the Empirical Literature," Journal of Economic Surveys 27, no. 2 (2013), 364-389, https://doi.org/10.1111/ j.1467-6419.2011.00711.x.

7 See for example Tom Clark, Robert D. Putnam and Edward Fieldhouse, The Age of Obama: The Changing Place of Minorities in British and American Society (Oxford: Oxford 
Decentralisation and regional autonomy have often been seen as an effective institutional setting to provide local public services efficiently and effectively, particularly in the presence of heterogeneity of the population. It is not by chance that the United States, Canada and Australia, countries that have their roots in migration, are among the most decentralised countries in the world, being in fact federal states. This is quite a common fact: countries where there are ethnic or linguistic minorities tend to be either federal or highly decentralised, such as for instance Canada, India, Nigeria and South Africa, to name a few. This is also evident in unitary countries - taking the form of asymmetric federalism - where there are minorities whose regional governments benefit from specific augmented forms of autonomy, as is the case in the United Kingdom, Spain, and Italy. ${ }^{8}$

Federalism, fiscal devolution and political decentralisation have been the major institutional reforms that have been carried out with the aim of reducing the gap, perceived as increasingly larger by citizens, between the government and territories. ${ }^{9}$ For these reasons, over the past decades, several countries have carried out reforms that go in the direction of 'bringing the government closer to the people. ${ }^{10}$ We can mention major constitutional reforms in Italy and Spain, as well as recent reforms in France; but also a stronger 'voice' rising from the bottom, through which regions claim greater autonomy, as the cases of the referendums in Scotland, Cataluña, and those recently experienced in two regions in the North of Italy, suggest.

This chapter brings together these two streams of research, both of which have addressed the provision of local public service and public policies, but from a different angle. The former has addressed the relationship between diversity and local public policies; the latter has dealt with the role of decentralisation and regional authority in the provision of local public services.

University Press, 2013); Edward Miguel and Mary Kay Gugerty, "Ethnic Diversity, Social Sanctions, and Public Goods in Kenya," Journal of Public Economics 89, no. 11 (2005), 2325-2368; Andreas P. Kyriacou, "Ethnic Segregation and the Quality of Government: The Importance of Regional Diversity," Constitutional Political Economy 23, no. 2 (2012), 78-101. Roger D. Congleton, Andreas Kyriacou and Jordi Bacaria, "A Theory of Menu Federalism: Decentralization by Political Agreement," Constitutional Political Economy 14, no. 3 (2003), 167-19o.

9 Jorge Martinez-Vazquez, Santiago Lago-Peñas and Agnese Sacchi, "The Impact of Fiscal Decentralization: A Survey," Journal of Economic Surveys 31, no. 4 (2016), 10951129, https://doi.org/10.1111/joes.12182; Luis Diaz-Serrano and Andrés Rodríguez-Pose, "Decentralization, Subjective Well-Being, and the Perception of Institutions," Kyklos 65, no. 2 (2012), 179-193, https://doi.org/10.1111/j.1467-6435.2012.00533.x.

10 Gary Marks, Liesbet Hooghe and Arjan H. Schakel, "Measuring Regional Authority," Regional and Federal Studies 18, no. 2-3 (2008), 167-181. 
More particularly, we investigate the relationship between diversity and the provision of local public service for European regions, exploring the following two research questions: $i$. Does diversity affect the provision of local public services? ii. Is regional autonomy a moderator between diversity and the provision of local public services? We do not look specifically at ethnic diversity, but we rather address the issue of national diversity; this allows us to extend the research to a wide sample of regions hence addressing a broader phenomenon which is relevant for EU policy.

The empirical analysis is based on 167 European regions. In order to measure the provision of local public goods at the regional level we employ the composite indicator developed by The Quality of Government (QoG Institute based on the citizens' perception about local public services. ${ }^{11}$ Hence, in this chapter the provision of local public services is measured in terms of citizens' satisfaction. On the one hand, as a subjective measure it does not assure a perfect overlap with the real functioning of public services. On the other hand, when it comes to policy, the perception of citizens is relevant, in that it drives their decisions. As far as the level of regional autonomy is concerned, we employ the Regional Authority Index developed by Hooghe, Gary and Schakel, ${ }^{12}$ these two indicators have a number of strengths and have been increasingly employed in this type of studies. ${ }^{13}$ Finally, a variable taking into account the diverse composition of the population - a diversity index - is developed following other studies; ${ }^{14}$ the index is based on the census of 2011 and considers three types of residents: native citizens, foreign EU residents, and foreign non-EU residents.

11 Quality of Government Institute of the University of Gothenborg, "Measuring the Quality of Government and Subnational Variation," Report for the European Commission Directorate-General Regional Policy Directorate Policy Development (December 2010), 1-48, https://ec.europa.eu/regional_policy/sources/docgener/studies/pdf/2010_government_1.pdf; Nicholas Charron and Victor Lapuente, "Why Do Some Regions in Europe Have Higher Quality of Government?," QoG Working Paper Series, no. 1 (January 2011), 1-38, https://www.pol.gu.se/digitalAssets/1357/1357846_2011_1_charron_lapuente.pdf.

12 Liesbet Hooghe, Gary Marks and Arjan H. Schakel, "Operationalizing Regional Authority: A Coding Scheme for 42 Countries, 1950-2006," Regional and Federal Studies 18, no. 2-3 (2008), 123-142.

13 See for example Nicholas Charron, Lewis Dijkstra, and Victor Lapuente, "Regional Governance Matters: Quality of Government within European Union Member States," Regional Studies 48, no. 1 (2014), 68-9o; Roberto Ezcurra and Andrés Rodríguez-Pose, "Political Decentralization, Economic Growth and Regional Disparities in the OECD," Regional Studies 47, no. 3 (2012), 1-14, https://doi.org/10.1080/00343404.2012.731046.

14 Alberto Alesina and Ekaterina Zhuravskaya, "Segregation and the Quality of Government in a Cross Section of Countries," The American Economic Review 101, no. 5 (2011), 18721911; Kyriacou, "Ethnic Segregation and the Quality of Government," 166-180; Ceren Ozgen, Peter Nijkamp and Jacques Poot, "The Impact of Cultural Diversity on Firm 
We find evidence that the presence of a heterogeneous population composition in the region is associated to a relatively worse performance in the provision of local public goods; regional autonomy can act, only partially, as a moderating mechanism between diversity and local public services.

The chapter is organised as follows. In the following section we put forward two hypotheses on the grounds of research on diversity and public policies, and research on fiscal federalism; section three presents our measures of public services, regional authority and diversity. Section four presents the empirical strategy and the results, while section five discusses them and concludes.

\section{Local Public Services, Diversity and Regional Autonomy: Two Hypotheses to Be Tested}

This chapter aims to bridge two different streams of research. The first deals with the impact of diversity on the provision of local public services..$^{15}$ The second deals with the role of federalism and regional autonomy, as a desirable institutional setting to deliver local public policies in the presence of heterogeneous communities. In what follows we derive two hypotheses regarding these two strands of research which will be tested in the empirical part.

\subsection{Diversity, Local Public Goods and Local Public Policies}

The provision of local public policies seems to become more problematic in the presence of a heterogeneous population. Alesina and Glaeser, for instance, foresee a reduction of the size of the welfare state in Europe as a result of increased immigration and fractionalisation. ${ }^{16}$ Empirical research finds that social spending, such as expenditure for public schools, government transfers, health spending etc. tend to be all negatively correlated with diversity. ${ }^{17}$ Several studies have addressed the phenomenon of ethnic diversity and the provision of public goods provision, particularly in developing countries where this phenomenon is more acute, suggesting several theoretical mechanisms and

Innovation: Evidence from Dutch Micro-Data," IZA Journal of Migration 2, no. 1 (2013), 1-18, https://doi.org/10.1186/2193-9039-2-18; Ceren Ozgen et al., "Does Cultural Diversity of Migrant Employees Affect Innovation?," International Migration Review 48, no. 1 (September 2014), 377-416, https://doi.org/10.1111/imre.12138.

15 In the remainder of the chapter the provision of local public services means the citizens' satisfaction about them.

16 Alesina and Glaeser, Fighting Poverty.

17 Stichnoth and van der Straeten, "Ethnic Diversity, Public Spending, and Individual Support for The Welfare State," 364-389. 
finding empirical evidence that ethnic diversity tends to undermine local public policies, e.g. education and health. ${ }^{18}$ Alesina, Baqir and Easterly find that the shares of spending on productive public goods in US cities are inversely related to the city's ethnic fragmentation, even after controlling for other socio-economic and demographic determinants. ${ }^{19}$ Cross-country studies tend to confirm these results. ${ }^{20}$

Two main possible arguments have been suggested to explain this finding. The first is an economic argument, and it foresees an increase in the demand of public welfare as a result of a more heterogeneous population. This is particularly true when migrants are relatively poorer than domestic citizens, which brings about an increase in the competition for local public goods. This will lead to - ceteris paribus - a deterioration in the provision of public services. Further, greater inequalities between groups have been found to undermine institutions and reduce government quality. ${ }^{21}$

The second argument is more sociological in nature. As Stichnoth and van der Straeten explain, "[i]f citizens are more supportive of redistribution when people from their own ethnic group benefit from it, ethnic diversity will reduce the support for redistribution, which in turn will tend to decrease the actual level of redistribution., ${ }^{22}$ Communities comprising of different ethnic or social groups can also lead to lower interaction, trust and social cohesion, ${ }^{23}$ relying

18 See for example James Habyarimana et al., "Why Does Ethnic Diversity Undermine Public Goods Provision?," American Political Science Review 101, no. 4 (2007), 709-725, https:// doi.org/10.1017/Sooo3055407070499; Miguel and Gugerty, "Ethnic Diversity,".

19 Alberto Alesina, Reza Baqir and William Easterly, "Public Goods and Ethnic Divisions," The Quarterly Journal of Economics 114, no. 4 (1999), 1243-1284, https://doi.org/10.1162/ oо3355399556269.

20 Alberto Alesina and Eliana La Ferrara, "Ethnic Diversity and Economic Performance," Journal of Economic Literature 43, no. 3 (September 2005), 762-80o, https://doi.org/ 10.1257/002205105774431243; Stichnoth and van der Straeten, "Ethnic Diversity, Public Spending, and Individual Support for The Welfare State," 364-389.

21 Andreas P. Kyriacou, "Ethnic Group Inequalities and Governance: Evidence from Developing Countries," Kyklos 6, no. 1 (2013), 78-101, https://doi.org/10.1111/kykl.12012.

22 Stichnoth and van der Straeten, "Ethnic Diversity, Public Spending, and Individual Support for The Welfare State," 370 .

23 See for example Dietlind Stolle, Stuart Soroka and Richard Johnston, "When Does Diversity Erode Trust? Neighborhood Diversity, Interpersonal Trust and the Mediating Effect of Social Interactions," Political Studies 56, no. 1 (2008), 57-75; Melissa J. Marschall and Dietlind Stolle, "Race and the City: Neighborhood Context and the Development of Generalized Trust," Political Behavior 26, no. 2 (2004), 125-153; Silvia Camussi, Anna Laura Mancini and Pietro Tommasino, "Does Trust Influence Social Expenditures? Evidence from Local Governments," Kyklos 71, no. 1 (2018), 59-85, https://doi.org/10.1111/kykl.12162; Henning Finseraas and Niklas Jakobsson, "Trust and Ethnic Fractionalization: The 
on the idea that an individual's behaviour and engagement are affected by the characteristics of her neighbours:

People (both natives and immigrants) generally prefer to live among people with the same background and are less likely to be willing to share resources with those who they perceive as different from themselves. They prefer to interact socially with others who share the same ethnic heritage, the same socioeconomic status, the same lifestyle, and who therefore share common interests, experiences and tastes or, put simply, people they have more to talk about with. ${ }^{24}$

This has been recently documented not only in the urban areas of the United States, but also in several European countries. ${ }^{25}$

For the reasons outlined above we derive the following hypothesis \#1:

Hip\#1: the higher the level of diversity in a region, the lower the performance in the provision of local public services.

\subsection{Regional Autonomy, Diversity and Public Services}

A central mechanism which connects diversity with dysfunctionality in public policy is the heterogeneity of preferences, in that heterogeneous tastes across ethnic groups are the channel through which diversity affects collective action. ${ }^{26}$ In their study on ethnic diversity and public goods in Kenya, Miguel and Gugerty discuss the implications of decentralisation of local public goods in communities characterised by high heterogeneity, and they raise two important arguments against the centralisation of public services in these cases. ${ }^{27}$ Firstly, in many less developed countries, central governments underprovide recurrent expenses. Secondly, centralisation of funding could lead to more regional and ethnic favouritism in the allocation of national government funds.

Importance of Religion as a Cross-Cutting Dimension," Kyklos 65, no. 3 (July 2012), 327339, https://doi.org/10.1111/j.1467-6435.2012.00541.X.

24 Vassilis Tselios, Philip McCann and Jouke van Dijk, "Understanding the Gap between Reality and Expectation: Local Social Engagement and Ethnic Concentration," Urban Studies 54, no. 11 (August 2017), 2592-2612, https://doi.org/10.1177/0042098016650395.

25 Stichnoth and van der Straeten, "Ethnic Diversity, Public Spending, and Individual Support for The Welfare State," $364-389$.

26 Alesina, Baqir and Easterly, "Public Goods and Ethnic Divisions," 1243-1284.

27 Miguel and Gugerty, "Ethnic Diversity," 1-11. 
If diversity affects economic choices and the outcome of public policies by directly entering individual preferences, ${ }^{28}$ then decentralisation and regional autonomy are natural candidates as effective institutional arrangements which can address the provision of local public services in the presence of diversity. Theories on fiscal federalism and decentralisation claim that regional autonomy improves the quality of local governments, both in terms of the efficiency and the level in the provision of public goods, ${ }^{29}$ accountability to citizens' preferences, ${ }^{30}$ and control of the public expenditure. ${ }^{31}$ By making the government closer to the people, regional autonomy is expected to provide local policies that are better able to respond to the differentiated needs arising in highly diverse regions; hence, regional authority is considered an effective solution to cope with the presence of high heterogeneous preferences at the regional/ local level. ${ }^{32}$

When it comes to the rationale for decentralisation and regional autonomy, local public services play a prominent role. As Serrano and Rodríguez-Pose put it, the primary aim of decentralisation has never been about delivering greater economic growth, reducing inequality or increasing social capital; rather, 'the original aim of decentralization is fundamentally to improve the delivering of public goods and services to individuals and, consequently, the level of satisfaction of the population with government.' ${ }^{33}$

Several counter arguments have been raised. Local governments can be less efficient than central governments; the provision of public services can benefit from economies of scale in the case of a central provision; issues of capture and corruption of local policy makers are easier to observe in a number of countries. ${ }^{34}$ Empirical research shows that countries with centralised governments

28 Alesina and La Ferrara, "Ethnic Diversity and Economic Performance," 762-8oo.

29 Mancur Olson, "Dictatorship, Democracy, and Development," American Political Science Review 87, no. 3 (1993), 567-576; Charles M. Tiebout, "A Pure Theory of Local Expenditures," Journal of Political Economy 64, no. 5 (1956), 416-424; Andrea Filippetti and Agnese Sacchi, "Decentralisation and Economic Growth Reconsidered: The Role of Regional Authority," Environment and Planning C: Government and Policy 34, no. 8 (2016), 1793-1824.

$30 \quad$ Wallace E. Oates, Fiscal Federalism (New York: Harcourt Brace Jonanovitch, 1972).

31 Geoffrey Brennan and James M. Buchanan, The Power to Tax: Analytic Foundations of a Fisc al Constitution (Cambridge: Cambrige University Press, 1980).

32 Tiebout, "A Pure Theory of Local Expenditures," 416-424.

33 Luis Diaz-Serrano and Andrés Rodríguez-Pose, "Decentralization, Happiness and the Perception of Institutions," IZA Discussion Paper, no. 5647 (April 2011), 2, 1-28, http:// papers.ssrn.com/sol3/papers.cfm?abstract_id=1812532; emphasis by the author of this chapter.

34 See for example Thushyanthan Baskaran and Lars P. Feld, "Fiscal Decentralization and Economic Growth in OECD Countries: Is There a Relationship?," Public Finance Review 41, no. 4 (July 2013), 421-445, https://doi.org/10.1177/1091142112463726; Vito Tanzi, "Pitfalls 
can also deliver local public services as efficiently as decentralised countries do. ${ }^{35}$ However, these criticisms are not directed towards the claim that regional authority works better in heterogeneous population.

Following on these lines of reasoning, we put forward the second hypothesis:

Hip\#2: regional autonomy is expected to moderate between diversity and the performance of local public services. [Put differently, for any given level of diversity, a higher level of regional autonomy is expected to be associated to a higher performance of local public services].

\section{Data: Measuring the Quality of Local Public Services and the Level of Regional Autonomy}

\subsection{The Provision of Local Public Services}

The organisation for the provision of local public services differs across countries depending primarily upon formal provisions at the level of the constitution. According to these, the type of state can be grouped in three broad categories: federal states, regionalised states, and unitary states. Firstly, we need to distinguish between exclusive competences attributed to the regional and local governments, and competences that are instead shared between the central government and the regional and local governments. Secondly, competences can be divided into legislative and administrative; typically, in unitary states the legislative competences belong to the central government, while the administrative competences can be attributed to different levels of subnational governments. In decentralised settings, such as federal or regionalised countries, both the legislative competences and the administrative competences of some local services can be attributed to the regional (and local) level. The revenue system for local public services also varies considerably across countries: in federal or regionalised states, regional governments often have some taxation power; by contrast, in unitary states local services tend to be financed through a mechanism of transfers from the central government. As a result, one can observe a great deal of heterogeneity when it comes to the regional

on the Road to Fiscal Decentralization," Working Papers, no. 19 (April 2001), 1-41, https:// carnegieendowment.org/files/19Tanzi.pdf.

35 Andrea Filippetti and Giovanni Cerulli, "Are Local Public Services Better Delivered in More Autonomous Regions? Evidence from European Regions Using a Dose-Response Approach," Papers in Regional Science 97, no. 3 (January 2017), 8o1-826, https://doi.org/ 10.1111/pirs.12283. 
competences across countries regarding the provision of public services, even when they are local services, such as for instance in the cases of education, public transport, health or local police. ${ }^{36}$ There are countries such as Bulgaria, Estonia, Lithuania, the Netherlands, Slovenia and Sweden where regions have no specific competences on their own; federal countries like Belgium, in which regional governments have no competences on education, or like Germany, in which instead the Länder have competences over a large number of services. Similar patterns can be found for other local public services (e.g. health). ${ }^{37}$

This chapter employs a composite indicator of the performance of local public services provided by the Quality of Government Survey based on the citizens' perception of three local public services: education, health and law enforcement. ${ }^{38}$ These are also those public services that are usually investigated in decentralisation studies. ${ }^{39}$ The indicator is a perception-based indicator built from a 34,00o-respondent survey from 172 regions within eighteen EU member states; to date, this constitutes one of the most comprehensive surveys about the quality of local public goods at the subnational level. ${ }^{40}$ The survey was undertaken between 15 December 2009, and 1 February 2010, and consisted of 34 questions to the approximately 200 respondents per region. Respondents were asked about three general public services in their regions education, health care and law enforcement. In focusing on these three services, respondents were asked to rate their public services with respect to three related concepts, namely the quality, impartiality and an inverse measure of the level of corruption of these services. ${ }^{41}$ The Survey also provides a single

36 European Institute of Public Administration (EIPA), "Division of Powers between the European Union, the Member States and Regional and Local Authorities," December 2012, https://cor.europa.eu/en/engage/studies/Documents/division_of_powers/division_ of_powers.pdf.

37 A comprehensive report on this issue can be consulted here: https://www.ifo.de/.

38 Charron, Dijkstra and Lapuente, "Regional Governance Matters,"; Quality of Government Institute of the University of Gothenborg, "Measuring the Quality of Government and Subnational Variation," $1-85$.

39 Agnese Sacchi and Simone Salotti, "A Comprehensive Analysis of Expenditure Decentralization and of the Composition of Local Public Spending," Regional Studies 50, no. 1 (2014), 1-17, https://doi.org/10.108o/oo343404.2014.893387.

40 Note that the authors call this index 'quality of government index' since they use the provision of local public goods as a proxy for the quality of regional government. Our focus here is instead on the quality of local public services themselves, exploiting the heterogeneity in their organisational structure across regions.

41 The complete questionnaire can be found in Quality of Government Institute of the University of Gothenborg, "Measuring the Quality of Government and Subnational Variation," appendix. 
QoG index for each region obtained by averaging the three pillars - quality, impartiality and (lack of) corruption, each weighted one third. In our analysis we will use both the overall qog index performance as well as the three pillars. ${ }^{42}$ The data have been standardised such that the EU regional mean is 'o' and has a standard deviation of ' 1 '. A series of extensive sensitivity tests were carried out to see whether changes in the model alter the final data. The results show that 'data constructed here are highly robust to multiple changes in weighting and aggregation schemes, the removal of individual questions or alterations in the demographic make-up of the respondents. ${ }^{43}$

The Report suggests the presence of a significant within-country variation from country to country. As explained by Charron and Lapuente, the data show that the indicator of $Q o G$ is either equally or more important than a variation between EU countries themselves. ${ }^{44}$ For example, some regions in Italy and Belgium perform like those in the best performing countries, while others rank similarly to low-performing regions in Hungary and Greece. This supports the case for an analysis at the regional level.

\subsection{The Degree of Regional Autonomy}

We employ a comprehensive measure of regional autonomy, the Regional Authority Index (RAI), ${ }^{45}$ which includes fiscal, political, and administrative measures of the authority of a regional government. This index has been used in these types of studies replacing measures of fiscal expenditures as proxy of decentralisation. ${ }^{46}$ The $R A I$ measures the authority of regional governments in 42 democracies or quasi-democracies on an annual basis over the period 1950-2016. The countries included are twenty-nine OECD countries, the 27 countries that are members of the European Union, as well as Albania, Bosnia and Herzegovina, Croatia, Macedonia, Russia, and Serbia and Montenegro.

42 In the chapter we will refer to overall performance to refer to the overall index, and to quality to refer to the single pillar 'quality'.

43 Quality of Government Institute of the University of Gothenborg, "Measuring the Quality of Government and Subnational Variation,".

44 Charron and Lapuente, "Why Do Some Regions in Europe Have Higher Quality of Government?," 567-582.

45 Hooghe, Marks and Schakel, "Operationalizing Regional Authority," 123-142; Marks, Hooghe and Schakel, "Measuring Regional Authority," 111-121.

46 See for example Ezcurra and Rodríguez-Pose, "Political Decentralization, Economic Growth and Regional Disparities," 1-14. 
The RAI is composed of two pillars, which respectively capture the degree of authority exerted by a regional government over its territory (self-rule) and over the whole country (shared-rule). Self-rule regards the degree of independence of the regional government from the influence of central authorities and the scope of regional decision-making. In turn, shared-rule measures the capacity of the regional government to determine central decisionmaking. ${ }^{47}$ It is worth stressing that despite the name of the indicator, the RAI refers not only to administrative decentralisation but also encompasses measures of political and fiscal decentralisation. As such, it is possibly the most comprehensive indicator of regional autonomy that has been developed so far.

\subsection{A Measure of National Diversity}

We calculated our measure of diversity by taking data from the census of $2011,{ }^{48}$ which considers for each region the following categories of citizens: native citizens, foreign EU residents, and foreign non-EU residents (including stateless). A typical measure of diversity can be obtained by subtracting the Herfindal index of the variable of interest from 1. In our case, this becomes (1 - Herfindal index of nationality shares), an approach also followed by others, e.g. Ozgen et al. ${ }^{49} \mathrm{~A}$ cursory look at the diversity indicators reveals a normal-shaped distribution with a tail on the right side that reflects the metropolitan areas of London, Brussels, and Vienna. Data are reported in Table 5.1.

47 Gary Marks, Liesbet Hooghe, and Arjan H. Schakel, "Patterns of Regional Authority," Regional and Federal Studies 18, no. 2-3 (2008), 167-181.

48 The data can be found here: https://ec.europa.eu/CensusHub2/query. do?step=selectHyperCube\&qhc=false.

49 Ozgen, Nijkamp and Poot, "The Impact of Cultural Diversity on Firm Innovation,; Ozgen et al., "Does Cultural Diversity of Migrant Employees Affect Innovation?," 377-416. 
TABLE 5.1 List of the regions and the three indicators

\begin{tabular}{llll}
\hline Region & $\begin{array}{l}\text { Index of } \\
\text { public } \\
\text { services }\end{array}$ & $\begin{array}{l}\text { Diversity } \\
\text { index }\end{array}$ & $\begin{array}{l}\text { Regional } \\
\text { authority } \\
\text { index }\end{array}$ \\
\hline
\end{tabular}

\begin{tabular}{|c|c|c|}
\hline AT_Burgenland & 1.274 & 0.114 \\
\hline AT_Lower Austria & 1.160 & 0.134 \\
\hline AT_Vienna & 0.993 & 0.362 \\
\hline AT_Carinthia & 0.880 & 0.136 \\
\hline AT_Styria & 0.848 & 0.132 \\
\hline AT_Upper Austria & 1.139 & 0.156 \\
\hline AT_Salzburg & 0.907 & 0.228 \\
\hline AT_Tyrol & 1.015 & 0.202 \\
\hline AT_Vorarlberg & 1.069 & 0.238 \\
\hline BE_Brussels-Capital Region & -0.369 & 0.491 \\
\hline BE_Flemish Region & 0.942 & 0.179 \\
\hline BE_Walloon Region & -0.008 & 0.175 \\
\hline BG_Severozapaden & -2.566 & 0.006 \\
\hline BG_Severen tsentralen & -2.061 & 0.009 \\
\hline BG_Severoiztochen & -0.915 & 0.013 \\
\hline BG_Yugoiztochen & -2.141 & 0.010 \\
\hline BG_Yugozapaden & -1.830 & 0.014 \\
\hline BG_Yuzhen tsentralen & -1.088 & 0.008 \\
\hline Cz_Prague & -0.903 & 0.256 \\
\hline Cz_Central Bohemian Region & -0.224 & 0.094 \\
\hline Cz_Jihozápad (Southwest) & -0.009 & 0.076 \\
\hline cz_Severozápad (Northwest) & -0.909 & 0.091 \\
\hline CZ_Severovýchod (Northeast) & -0.110 & 0.063 \\
\hline CZ_Jihovchod (Southeast) & -0.441 & 0.059 \\
\hline Cz_Stední Morava (Central Moravia) & -0.534 & 0.031 \\
\hline Cz_Moravian-Silesian Region & -0.361 & 0.038 \\
\hline D K_Hovedstaden & 1.306 & 0.176 \\
\hline DK_Sjlland & 1.448 & 0.080 \\
\hline DK_Syddanmark & 1.440 & 0.100 \\
\hline DK_Midtjylland & 1.687 & 0.099 \\
\hline D K_Nordjylland & 1.317 & 0.080 \\
\hline DE_Baden-Württemberg & 0.981 & 0.205 \\
\hline DE_Bavaria & 0.712 & 0.184 \\
\hline DE_Berlin & 0.981 & 0.205 \\
\hline
\end{tabular}


TABLE 5.1 List of the regions and the three indicators (cont.)

\begin{tabular}{llll}
\hline Region & $\begin{array}{l}\text { Index of } \\
\text { public } \\
\text { services }\end{array}$ & $\begin{array}{l}\text { Diversity } \\
\text { index }\end{array}$ & $\begin{array}{l}\text { Regional } \\
\text { authority } \\
\text { index }\end{array}$ \\
\hline
\end{tabular}

\begin{tabular}{|c|c|c|c|}
\hline DE_Brandenburg & 0.979 & 0.032 & 21 \\
\hline DE_Bremen & 0.953 & 0.196 & 21 \\
\hline DE_Hamburg & 0.961 & 0.219 & 21 \\
\hline DE_Hessen & 0.630 & 0.202 & 21 \\
\hline DE_Mecklenburg-Vorpommern & 0.937 & 0.174 & 21 \\
\hline DE_Lower Saxony & 0.949 & 0.142 & 21 \\
\hline DE_North Rhine-Westphalia & 0.714 & 0.037 & 21 \\
\hline DE_Rhineland-Palatinate & 0.827 & 0.037 & 21 \\
\hline DE_Saarland & 1.051 & 0.141 & 21 \\
\hline DE_Saxony & 1.096 & 0.141 & 21 \\
\hline DE_Saxony-Anhalt & 0.866 & 0.141 & 21 \\
\hline DE_Schleswig-Holstein & 1.273 & 0.059 & 21 \\
\hline DE_Thuringia & 1.336 & 0.051 & 21 \\
\hline FR_île-de-France & 0.547 & 0.226 & 8 \\
\hline FR_Champagne-Ardenne & 0.185 & 0.074 & 8 \\
\hline FR_Picardie & 0.471 & 0.064 & 8 \\
\hline FR_Haute-Normandie & 0.123 & 0.056 & 8 \\
\hline FR_Centre & 0.613 & 0.081 & 8 \\
\hline FR_Basse-Normandie & 0.502 & 0.039 & 8 \\
\hline FR_Bourgogne & 0.485 & 0.076 & 8 \\
\hline FR_Nord-Pas-de-Calais & 0.544 & 0.063 & 8 \\
\hline FR_Lorraine & 0.244 & 0.099 & 8 \\
\hline FR_Alsace & 0.475 & 0.143 & 8 \\
\hline FR_Franche-Comté & 0.494 & 0.086 & 8 \\
\hline FR_Pays de la Loire & 0.357 & 0.040 & 8 \\
\hline FR_Bretagne & 1.043 & 0.039 & 8 \\
\hline FR_Poitou-Charentes & 0.768 & 0.054 & 8 \\
\hline FR_Aquitaine & 0.820 & 0.083 & 8 \\
\hline FR_Midi-Pyrénées & 0.394 & 0.089 & 8 \\
\hline FR_Limousin & 0.727 & 0.085 & 8 \\
\hline FR_Rhine-Alpes & 0.800 & 0.122 & 8 \\
\hline FR_Auvergne & $0.5^{6} 3$ & 0.063 & 8 \\
\hline FR_Languedoc-Roussillon & 0.536 & 0.110 & 8 \\
\hline FR_Provence-Alpes-Cote d'Azur & 0.215 & 0.119 & \\
\hline
\end{tabular}


TABLE 5.1 List of the regions and the three indicators (cont.)

\begin{tabular}{llll}
\hline Region & $\begin{array}{l}\text { Index of } \\
\text { public } \\
\text { services }\end{array}$ & $\begin{array}{l}\text { Diversity } \\
\text { index }\end{array}$ & $\begin{array}{l}\text { Regional } \\
\text { authority } \\
\text { index }\end{array}$ \\
\hline
\end{tabular}

\begin{tabular}{|c|c|c|}
\hline FR_Corse & 0.123 & 0.159 \\
\hline GR_Voreia Ellada & -1.389 & 0.118 \\
\hline GR_Kentriki Ellada & -1.069 & 0.118 \\
\hline GR_Attica & -0.261 & 0.193 \\
\hline GR_Nisia Aigaiou, Kriti & -0.912 & 0.208 \\
\hline HU_Central Hungary & -1.018 & 0.049 \\
\hline HU_Transdanubia & -0.320 & 0.025 \\
\hline HU_Great Plain and North & -0.439 & 0.017 \\
\hline IT_Piemonte & -0.118 & 0.154 \\
\hline IT_Valle d'Aosta & o.696 & 0.126 \\
\hline IT_Liguria & -0.507 & 0.133 \\
\hline IT_Lombardia & -0.638 & 0.179 \\
\hline IT_Trentino-Alto Adige (Bolzano) & 0.832 & 0.147 \\
\hline IT_Trentino-Alto Adige (Trento) & 0.538 & 0.162 \\
\hline IT_Veneto & -0.462 & 0.174 \\
\hline IT_Friuli-Venezia Giulia & 0.199 & 0.149 \\
\hline IT_Emilia-Romagna & -0.341 & 0.190 \\
\hline IT_Toscana & $-0.55^{\circ}$ & 0.163 \\
\hline IT_Umbria & -0.190 & 0.183 \\
\hline IT_Marche & -0.460 & 0.161 \\
\hline IT_Lazio & -1.267 & 0.146 \\
\hline IT_Abruzzo & -0.908 & 0.100 \\
\hline IT_Molise & -1.236 & 0.050 \\
\hline IT_Campania & -2.318 & 0.050 \\
\hline IT_Puglia & -1.735 & 0.040 \\
\hline IT_Basilicata & -1.259 & 0.044 \\
\hline IT_Calabria & -2.189 & 0.065 \\
\hline IT_Sicilia & -1.828 & 0.049 \\
\hline IT_Sardegna & -0.887 & 0.037 \\
\hline NL_Northern Netherlands & 1.625 & 0.075 \\
\hline NL_Eastern Netherlands & 1.179 & 0.036 \\
\hline NL_Western Netherlands & 1.273 & 0.053 \\
\hline NL_Southern Netherlands & 1.077 & 0.123 \\
\hline PL_Lodzkie & -0.846 & 0.005 \\
\hline
\end{tabular}


TABLE 5.1 List of the regions and the three indicators (cont.)

\begin{tabular}{llll}
\hline Region & $\begin{array}{l}\text { Index of } \\
\text { public } \\
\text { services }\end{array}$ & $\begin{array}{l}\text { Diversity } \\
\text { index }\end{array}$ & $\begin{array}{l}\text { Regional } \\
\text { authority } \\
\text { index }\end{array}$ \\
\hline
\end{tabular}

\begin{tabular}{|c|c|c|}
\hline PL_Mazowieckie & -0.996 & 0.010 \\
\hline PL_Malopolskie & -0.875 & 0.004 \\
\hline PL_Slaskie & -1.115 & 0.003 \\
\hline PL_Lubelskie & -0.904 & 0.004 \\
\hline PL_Podkarpackie & $-0.85^{2}$ & 0.003 \\
\hline PL_Swietokrzyskie & -0.804 & 0.002 \\
\hline PL_Podlaskie & -0.962 & 0.006 \\
\hline PL_Wielkopolskie & -0.999 & 0.003 \\
\hline PL_Zachodniopomorskie & -0.867 & 0.005 \\
\hline PL_Lubuskie & -0.929 & 0.006 \\
\hline PL_Dolnoslaskie & -1.116 & 0.006 \\
\hline PL_Opolskie & -0.611 & 0.005 \\
\hline PL_Kujawsko-Pomorskie & -0.949 & 0.003 \\
\hline PL_Warminsko-Mazurskie & -0.668 & 0.003 \\
\hline PL_Pomorskie & $-0.85^{8}$ & 0.004 \\
\hline PT_Norte & -0.322 & 0.028 \\
\hline PT_Algarve & 0.208 & 0.211 \\
\hline PT_Centro & -0.029 & 0.046 \\
\hline PT_Lisboa & 0.141 & 0.135 \\
\hline PT_Alentejo & 0.738 & 0.061 \\
\hline PT_Azores & $0.5^{12}$ & 0.027 \\
\hline PT_Madeira & 0.280 & 0.041 \\
\hline RO_North-West & -1.135 & 0.004 \\
\hline RO_Centru & -1.581 & 0.002 \\
\hline RO_North-East & -2.014 & 0.003 \\
\hline RO_South-East & -2.035 & 0.002 \\
\hline RO_South-Muntenia & -1.774 & 0.001 \\
\hline RO_Bucharest-Ilfov & -2.964 & 0.011 \\
\hline RO_South-West Oltenia & -1.478 & 0.001 \\
\hline RO_West & -2.250 & 0.005 \\
\hline SK_Bratislava Region & -0.572 & 0.095 \\
\hline sk_Western Slovakia & -0.863 & 0.128 \\
\hline SK_Central Slovakia & -0.766 & 0.166 \\
\hline sk_Eastern Slovakia & -0.769 & 0.182 \\
\hline
\end{tabular}


TABLE 5.1 List of the regions and the three indicators (cont.)

\begin{tabular}{|c|c|c|c|}
\hline Region & $\begin{array}{l}\text { Index of } \\
\text { public } \\
\text { services }\end{array}$ & $\begin{array}{l}\text { Diversity } \\
\text { index }\end{array}$ & $\begin{array}{l}\text { Regional } \\
\text { authority } \\
\text { index }\end{array}$ \\
\hline ES_Galicia & 0.574 & 0.073 & 15 \\
\hline ES_Asturias & 0.512 & 0.086 & 15 \\
\hline ES_Basque Community & 0.665 & 0.123 & 16 \\
\hline ES_Navarre & 0.173 & 0.188 & 16 \\
\hline ES_La Rioja & 0.243 & 0.246 & 15 \\
\hline ES_Aragon & 0.320 & 0.223 & 15 \\
\hline ES_Madrid & -0.098 & 0.261 & 15 \\
\hline ES_Castile-Leon & -0.055 & 0.122 & 15 \\
\hline ES_Castile-La Mancha & 0.208 & 0.189 & 15 \\
\hline ES_Extremadura & 0.416 & 0.068 & 15 \\
\hline ES_Catalonia & -0.464 & 0.264 & 15 \\
\hline ES_Valencian Community & 0.154 & 0.268 & 15 \\
\hline ES_Balearic Islands & 0.109 & 0.342 & 15 \\
\hline ES_Andalusia & 0.284 & 0.148 & 15 \\
\hline ES_Region of Murcia & -0.036 & 0.270 & 15 \\
\hline ES_Canarias & 0.272 & 0.239 & 15 \\
\hline SE_East Sweden & 1.376 & 0.185 & 10 \\
\hline SE_South Sweden & 1.453 & 0.114 & 10 \\
\hline SE_North Sweden & 1.260 & 0.097 & 10 \\
\hline UK_North East. England & 0.919 & 0.045 & 4 \\
\hline UK_North West. England & 1.040 & 0.067 & 4 \\
\hline UK_Yorkshire and the Humber. Eng. & 0.652 & 0.099 & 4 \\
\hline U K_East Midlands. England & 1.245 & 0.131 & 4 \\
\hline UK_West Midlands. England & 0.800 & 0.067 & 4 \\
\hline UK_East of England & 0.763 & 0.075 & 4 \\
\hline UK_London. England & 0.484 & 0.362 & 9 \\
\hline UK_South East. England & 1.082 & 0.124 & 4 \\
\hline UK_South West. England & 1.091 & 0.117 & 4 \\
\hline UK_Wales & $0.8 \circ 6$ & 0.067 & 12 \\
\hline UK_Scotland & 1.277 & 0.090 & 17 \\
\hline UK_Northern Ireland & 0.933 & 0.361 & 10 \\
\hline
\end{tabular}




\section{$4 \quad$ Analysis and Results}

\subsection{Estimation Strategy}

In order to test our hypotheses, we estimate a cross-section model of 167 regions in Europe employing ordinary least squares (OLS) method, with standard errors clustered around the region (see Table 5.2 for pairwise correlations). The models look as follows:

Servicesi $=\alpha+\beta_{1}$ diversityi $+\beta_{2}$ controlsi $+\varepsilon i$

Servicesi $=\alpha+\beta_{1}$ controlsi $+\beta_{2}$ reg_autonomyi $+\beta_{3}$ diversityi $+\beta_{4}$ reg_autonomyi diversityi $+\varepsilon i$

Eq. 1 tests the first hypothesis (coefficient $\beta_{1}$ ), while eq. 2 , which includes an interaction effect between regional autonomy and diversity (coefficient $\beta_{4}$ ), tests the second hypothesis.

Several control variables at the region level are included, namely: income per capita (here measured in PPP); three dummy variables controlling for i) bilingual region; $i i$ ) autonomous region; ${ }^{50}$ iii) capital region; the (log of) population. A customary variable which is taken into account in political economy studies is the presence of strong and independent media, since they are considered an important channel through which citizens can monitor the local policy makers. For this reason, we have included the variable 'independent media' which reflects 'the strength and effectiveness of the media in the region to expose corruption' and is part of the same QoG Survey. We also employ the share of citizens with tertiary education, as an overall proxy of the level of education of the people living in the region. Finally, we introduce our measure of diversity - the diversity index. Eq. 2 includes the same control variables, but it further includes our measure of regional autonomy jointly with the diversity index.

\subsection{Local Public Services, Diversity and Regional Autonomy}

Table 5.3 reports the results of our estimates of the model above (1). Column (1) reports the results for the overall index of local services, while the others report the results for each of the indicators: impartiality (2), corruption (3) and quality of services (4). The coefficients of the control variables are in line with what was expected. Income per capita predicts high scores in the provision of local services. Autonomous regions seem to be negatively correlated with public services, although the coefficients are never significant. Being a

$5^{\circ}$ While this variable is clearly correlated with our measure of regional authority (rate of correlation equal to 0.20 ), autonomous regions often tend to receive considerable transfer from central states, thus it is important to control for this specific status. 


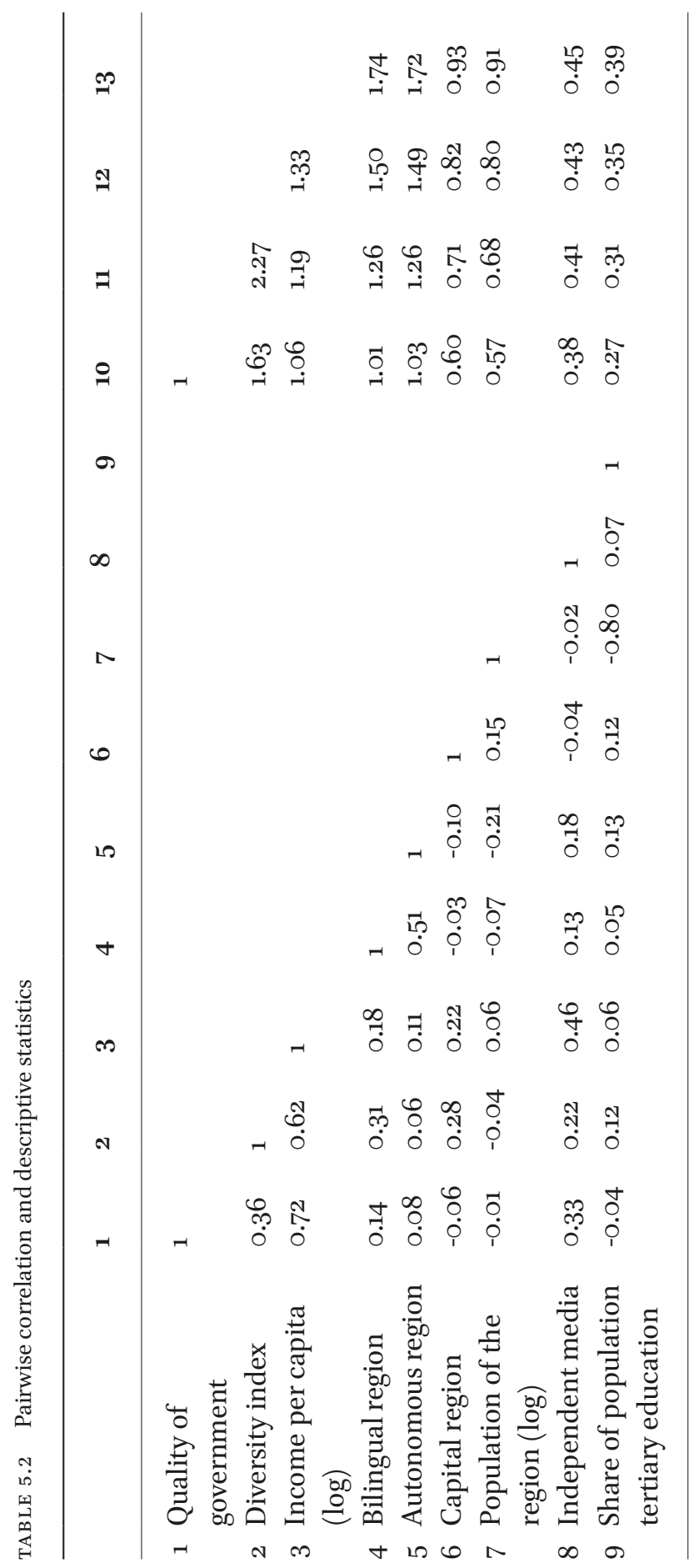


TABLE 5.3 Impartiality, regional autonomy and diversity

\begin{tabular}{|c|c|c|c|c|}
\hline & (1) & $(2)$ & (3) & (4) \\
\hline & Overall & Impartiality & Corruption & Quality \\
\hline Diversity index & $\begin{array}{l}-1.615^{* *} \\
(0.799)\end{array}$ & $\begin{array}{l}1.559 \\
(1.186)\end{array}$ & $\begin{array}{l}-1.609 * \\
(0.929)\end{array}$ & $\begin{array}{l}-3.473^{* * *} \\
(0.842)\end{array}$ \\
\hline Income per capita & $\begin{array}{l}1.453^{* * *} \\
(0.108)\end{array}$ & $\begin{array}{l}0.5^{22^{* * *}} \\
(0.159)\end{array}$ & $\begin{array}{l}1.155^{* * *} \\
(0.122)\end{array}$ & $\begin{array}{l}0.865^{* * *} \\
(0.170)\end{array}$ \\
\hline Bilingual region & $\begin{array}{l}0.200 \\
(0.188)\end{array}$ & $\begin{array}{l}0.506 \\
(0.314)\end{array}$ & $\begin{array}{l}0.481^{* * *} \\
(0.170)\end{array}$ & $\begin{array}{l}0.326 \\
(0.265)\end{array}$ \\
\hline Autonomous region & $\begin{array}{l}-0.266 \\
(0.230)\end{array}$ & $\begin{array}{l}-0.149 \\
(0.227)\end{array}$ & $\begin{array}{l}-0.233 \\
(0.177)\end{array}$ & $\begin{array}{l}-0.121 \\
(0.259)\end{array}$ \\
\hline Capital region & $\begin{array}{l}-0.433^{*} \\
(0.220)\end{array}$ & $\begin{array}{l}-0.409 \\
(0.259)\end{array}$ & $\begin{array}{l}-0.516^{*} \\
(0.276)\end{array}$ & $\begin{array}{l}-0.130 \\
(0.187)\end{array}$ \\
\hline Population of the region & $\begin{array}{l}-0.414^{* * *} \\
(0.129)\end{array}$ & $\begin{array}{l}-0.211 \\
(0.157)\end{array}$ & $\begin{array}{l}-0.277^{* *} \\
(0.120)\end{array}$ & $\begin{array}{l}-0.0911 \\
(0.148)\end{array}$ \\
\hline Independent media & $\begin{array}{l}-0.0402 \\
(0.0602)\end{array}$ & $\begin{array}{l}0.216 * * * \\
(0.0690)\end{array}$ & $\begin{array}{l}0.176 * * * \\
(0.0662)\end{array}$ & $\begin{array}{l}0.483^{* * *} \\
(0.0661)\end{array}$ \\
\hline $\begin{array}{l}\text { Population with tertiary } \\
\text { education }\end{array}$ & $\begin{array}{l}-0.409^{* * *} \\
(0.126)\end{array}$ & $\begin{array}{l}-0.246 \\
(0.167)\end{array}$ & $\begin{array}{l}-0.289^{* *} \\
(0.129)\end{array}$ & $\begin{array}{l}-0.172 \\
(0.147)\end{array}$ \\
\hline Constant & $\begin{array}{l}-12.47^{* * *} \\
(1.154)\end{array}$ & $\begin{array}{l}-4.576^{* *} \\
(1.768)\end{array}$ & $\begin{array}{l}-10.15^{* * *} \\
(1.220)\end{array}$ & $\begin{array}{l}-8.096^{* * *} \\
(1.842)\end{array}$ \\
\hline Observations & 167 & 167 & 167 & 167 \\
\hline$R^{2}$ & 0.621 & 0.365 & 0.567 & 0.592 \\
\hline
\end{tabular}

capital region, along with the size of the region (as measured by population), are negatively correlated with services; this might depend on the presence of congestion effects. The presence of independent media is positively correlated with services, while the level of education is instead negatively correlated with the dependent variable (we discuss this further below).

By focussing on the explanatory variable - our measure of diversity - the related coefficient is negative and significant for the overall provision of public services (significant at $5 \%$ ), corruption (significant at $10 \%$ ), and their quality (significant at $1 \%$ ). This supports our hypothesis no. 1.

In this second set of estimates we interact our measure of diversity with two variables, namely the presence of independent media and the level of education. Table 5.4 reports the same estimates as for Table 5.3, but with the inclusion of 


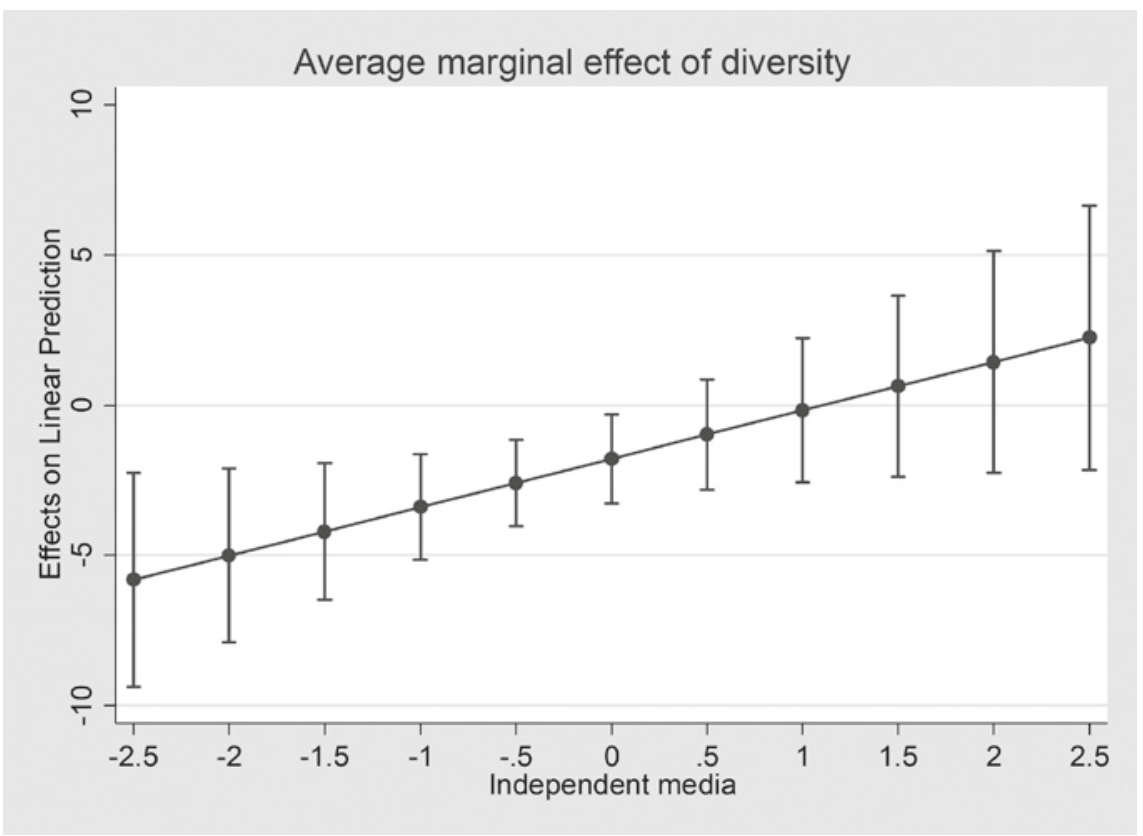

FIGURE 5.1 The effect of diversity on the provision of local services when independent media changes

the following interaction term: presence of independent media\#diversity (column 1), and the level of education\#diversity (column 2). The rationale is that both independent media and the level of education should mitigate the presence of bias in perception, if present. More independent media will provide more impartial information for citizens, whilst more educated people should be better equipped to process public information objectively. By looking at the results, only the presence of independent media seems to moderate the negative effect of diversity on services. As the chart in Figure 5.1 shows, the negative effect of diversity on services approaches zero and then turns positive (although not statistically significant) as long as the variable independent media grows. This suggests the presence of some misperception in the functioning of local public services which are attenuated when there are independent media in the region.

We now turn to our second hypothesis, which states that the presence of regional autonomy is expected to moderate between diversity and the performance of local public services. In order to test the moderating effect of regional authority we include the variable diversity\#regional autonomy. Table 5.5 reports the estimate of the model as in eq. 2 , for the main index of services and the three pillars - impartiality, corruption and quality. The coefficient of the joint effect of diversity and regional autonomy is positive and significant (at $5 \%$ ) 
TABLE 5.4 Testing education and the presence of independent media

(1)

$(2)$

$\begin{array}{ll}\begin{array}{l}\text { Quality of } \\ \text { government }\end{array} & \begin{array}{l}\text { Quality of } \\ \text { government }\end{array}\end{array}$

$\begin{array}{lll}\begin{array}{l}\text { Diversity index \# Population with tertiary } \\ \text { education }\end{array} & \begin{array}{l}-\mathbf{0 . 3 1 5} \\ \mathbf{( o . 7 0 1 )}\end{array} \\ \text { Diversity index } & -2.699 & -1.786^{* *} \\ & (2.766) & \left(0.75^{2}\right) \\ \text { Independent media } & -0.0377 & -0.236^{* *} \\ & (0.0604) & (0.115) \\ \text { Population with tertiary education } & -0.371^{* * *} & -0.413^{* * *} \\ & (0.172) & (0.123) \\ \text { Diversity index \# Independent media } & & \mathbf{1 . 6 1 3 ^ { * * }} \\ & & (\boldsymbol{o . 7 5 2 )}\end{array}$

All controls included as for Table 1

$\begin{array}{lll}\text { Constant } & -12.29^{* * *} & -12.94^{* * * *} \\ & (1.802) & (1.801) \\ \text { Observations } & 167 & 167 \\ R^{2} & 0.622 & 0.632\end{array}$

limited to the case of the quality of services (column 4). By looking at Figure 5.2 reporting the average marginal effect of diversity along the levels of regional autonomy, it can be seen that the negative correlation of diversity with the quality of local public services moves closer to zero for high levels of regional autonomy. In regions in which regional autonomy is quite high (higher than 18.5), the marginal effect of diversity is still moderately negative but no longer significant. This suggests the presence of some moderating effect of regional autonomy on the relationship between diversity and the quality of local public services, although limited to their quality, in that the only significant coefficient regards the estimates of quality (column 4 of Table 5.5).

Dealing with diversity in the European regions has become imperative in European and national policy agendas. Internal mobility is a cornerstone of 


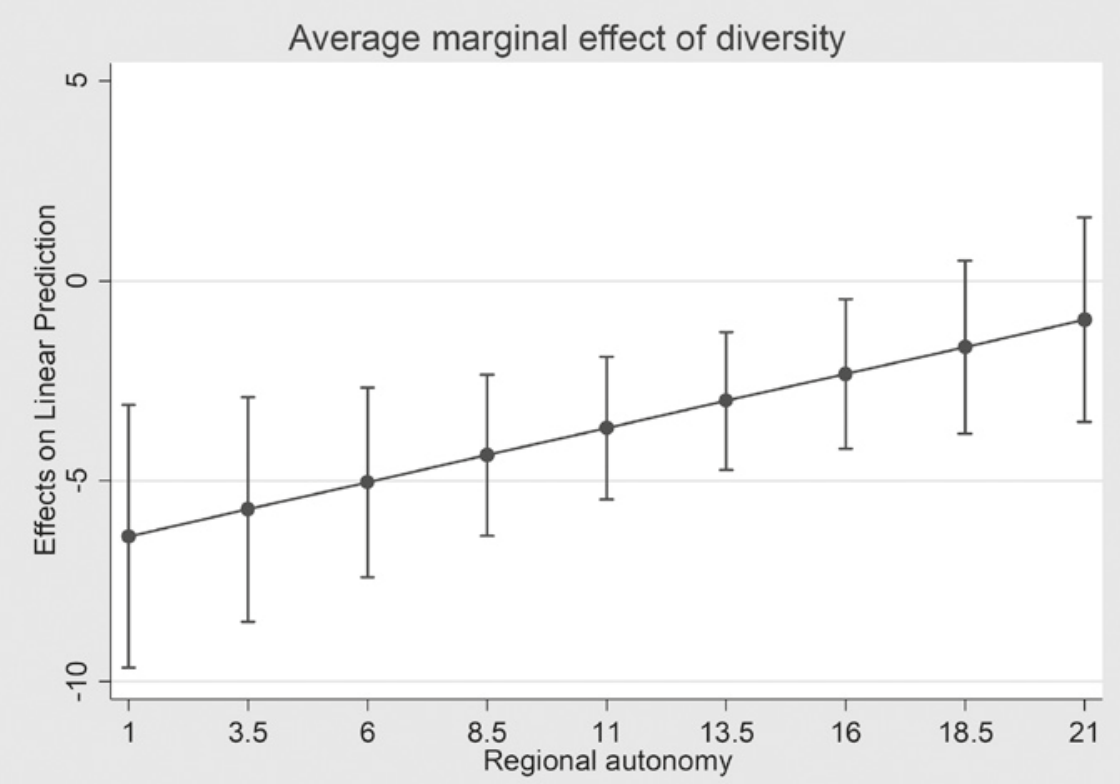

FIGURE 5.2 The effect of diversity on the provision of local services when regional autonomy changes

TABLE 5.5 Testing the moderating effect of regional authority
(1)
(2)
(3)
(4)

\section{Overall Impartiality Corruption Quality}

\begin{tabular}{|c|c|c|c|c|}
\hline Diversity index & $\begin{array}{l}-1.620 \\
(1.832)\end{array}$ & $\begin{array}{l}2.704 \\
(2.457)\end{array}$ & $\begin{array}{l}-2.605 \\
(2.301)\end{array}$ & $\begin{array}{l}-6.647^{* * *} \\
(1.765)\end{array}$ \\
\hline Regional autonomy & $\begin{array}{l}-0.00415 \\
(0.0203)\end{array}$ & $\begin{array}{l}0.0785^{* * * *} \\
(0.0267)\end{array}$ & $\begin{array}{l}-0.00374 \\
(0.0180)\end{array}$ & $\begin{array}{l}-0.0637^{* * *} \\
(0.0166)\end{array}$ \\
\hline \multirow[t]{2}{*}{$\begin{array}{l}\text { Diversity index \# Regional } \\
\text { autonomy }\end{array}$} & 0.0007 & -0.141 & 0.0721 & $0.270^{* *}$ \\
\hline & $(0.136)$ & $(0.192)$ & $(0.140)$ & $(0.118)$ \\
\hline
\end{tabular}

All controls included as Table 1

\begin{tabular}{lllll} 
Constant & $-12.48^{* * *}$ & -2.406 & $-10.26^{* * *}$ & $-9.872^{* * *}$ \\
& $(1.196)$ & $(1.661)$ & $(1.272)$ & $(1.751)$ \\
Observations & 167 & 167 & 167 & 167 \\
$R^{2}$ & 0.621 & 0.446 & 0.568 & 0.621 \\
\hline
\end{tabular}


the EU policy, and the more new members join the EU, the more migration within the EU is bound to grow. Additionally, migration from outside the EU borders is also expected to grow considerably. Empirical studies carried out mostly in the Unites States and in some developing countries have by and large found that when ethnic diversity grows, the welfare state, the provision of public goods, and income redistribution tend to become more problematic. For European countries and regions, this will be one of the most relevant issues to deal with in the coming years.

This chapter provides evidence that $i$ ) the presence of a heterogeneous composition of population in the European regions is associated to a relatively worse public perception of the provision of local public goods; and $i i$ ) regional autonomy (to some extent) can act as a moderating mechanism between diversity and local public services.

The first result is in line with theories about diversity and public policy, and with several empirical studies that detected a negative correlation between diversity and the provision of public goods. As a matter of fact, most of this research has been carried out in cities and countries with a high presence of ethnic heterogeneity, as for instance in some American cities, and in some developing countries; to our knowledge this is the first attempt carried out across a large sample of European regions.

Another difference of this study is that our measure of diversity does not take into account ethnicity or socio-economic status but is limited to nationality. On the one hand this has some clear limitations, in that ethnic diversity is a remarkable source of heterogeneity. However, our broader measure of diversity allows us to address one of the cornerstones of European integration, that of the internal mobility of the labour force. Internal mobility has often been identified by policy makers as a fundamental driver of reciprocal learning, a carrier of knowledge, as well as a great means to make the labour market work more efficiently, by reducing disparities in the rates of unemployment across European countries. As such, the internal mobility of citizens is regarded as a pillar of social cohesion in Europe. However, recent debates have redirected attention to a number of problems that internal migration can create on the sustainability of the welfare states of recipient countries. Within this context, our evidence raises an issue for policy makers. This will be further exacerbated by the fact that since our data refer to 2011, it is more than likely that diversity has increased since, both because of an increase in mobility within Europe since the financial crisis in 2008, and due to the recent surge in migration from outside the EU. This calls for future research with updated census data.

It is also possible that our data underestimates the pressure of illegal immigrants on the welfare state; they are not captured by data on foreign residents, 
but can, however, benefit from some local public services, particularly public health. Finally, we do not take into account within-country mobility which can in some cases be an additional source of diversity and pressure on local welfare.

Our second piece of evidence shows that regional authority can have a moderating effect between diversity and the provision of local services. This partially confirms one of the main claims of fiscal federalism theory, according to which bringing political authority and administration closer to the people is effective, particularly when there are heterogeneous local communities which are likely to be reflected in heterogeneous preferences. In these cases, regional authority should be more effective than centralisation in making local public policies more responsive to the heterogeneous preferences. There are counter arguments that are worth mentioning. Firstly, local governments can be more easily captured, as well as corrupted, by local constituencies. Secondly, in times of crisis and budget constraints, regional governments can have fewer resources to devote to welfare. Hence, it is possible that central governments are more effective than regional governments in dealing with a swift increase in the demand for local public services, to the extent that they are able to mobilise a larger amount of resources. Further, more centralised governments can be better equipped in managing migration flows than more decentralised ones, for example by being better able to redistribute immigrants, thus avoiding excessive concentrations in some regions. These are open questions that remain to be explored at greater lengths and with more recent data.

\section{Bibliography}

Alesina, Alberto, Reza Baqir and William Easterly. "Public Goods and Ethnic Divisions." The Quarterly Journal of Economics 114, no. 4 (1999): 1243-1284. https://doi.org/ 10.1162/oo3355399556269.

Alesina, Alberto, and Eliana La Ferrara. "Ethnic Diversity and Economic Performance." Journal of Economic Literature 43, no. 3 (September 2005): 762-80o. https://doi.org/ 10.1257/002205105774431243.

Alesina, Alberto, and Edward Ludwig Glaeser. Fighting Poverty in the US and Europe: A World of Difference. Oxford: Oxford University Press, 2004.

Alesina, Alberto, and Ekaterina Zhuravskaya. "Segregation and the Quality of Government in a Cross Section of Countries." The American Economic Review 101, no. 5 (2011): 1872-1911.

Baskaran, Thushyanthan, and Lars P. Feld. "Fiscal Decentralization and Economic Growth in OECD Countries: Is There a Relationship?." Public Finance Review 41, no. 4 (July 2013): 421-445. https://doi.org/10.1177/1091142112463726. 
Brennan, Geoffrey and James M. Buchanan. The Power to Tax: Analytic Foundations of a Fiscal Constitution, Cambridge: Cambridge University Press, 1980.

Camussi, Silvia, Anna Laura Mancini and Pietro Tommasino. "Does Trust Influence Social Expenditures? Evidence from Local Governments." Kyklos 71, no. 1 (2018): 5985. https://doi.org/10.1111/kykl.12162.

Charron, Nicholas, and Victor Lapuente. "Why Do Some Regions in Europe Have Higher Quality of Government?." QoG Working Paper Series, no. 1 (January 2011): 138. https://www.pol.gu.se/digitalAssets/1357/1357846_2011_1_charron_lapuente.pdf. Charron, Nicholas, Lewis Dijkstra and Victor Lapuente. "Regional Governance Matters: Quality of Government within European Union Member States." Regional Studies 48, no. 1 (2014): 68-9o.

Christainsen, Gregory B. "Biology, Immigration, and Public Policy." Kyklos 65, no. 2 (2012): 164-178. https://doi.org/10.1111/j.1467-6435.2012.00532.x.

Clark, Tom, Robert D. Putnam and Edward Fieldhouse. The Age of Obama:The Changing Place of Minorities in British and American Society. Oxford: Oxford University Press, 2013.

Congleton, Roger D., Andreas Kyriacou and Jordi Bacaria. "A Theory of Menu Federalism: Decentralization by Political Agreement." Constitutional Political Economy 14, no. 3 (2003): 167-19o.

Cutler, David M., Douglas W. Elmendorf and Richard J. Zeckhauser. "Demographic Characteristics and the Public Bundle." National Bureau of Economic Research NBER Working Paper, no. 4283 (February 1993): 1-55. https://doi.org/10.3386/w4283.

Dennison, James, and Andrew Geddes. "Brexit and the Perils of 'Europeanised' Migration." Journal of European Public Policy 25, no. 8 (2018): 1137-1153. https://doi. org/10.108o/13501763.2018.1467953.

Diaz-Serrano, Luis, and Andrés Rodríguez-Pose. "Decentralization, Happiness and the Perception of Institutions.” IZA Discussion Paper, no. 5647 (April 2011).: 1-28. http:// papers.ssrn.com/sol3/papers.cfm?abstract_id=1812532.

Diaz-Serrano, Luis, and Andrés Rodríguez-Pose. "Decentralization, Subjective WellBeing, and the Perception of Institutions." Kyklos 65, no. 2 (2012): 179-193. https:// doi.org/10.1111/j.1467-6435.2012.00533.x.

European Institute of Public Administration (EIPA). "Division of Powers between the European Union, the Member States and Regional and Local Authorities." December 2012: Page range. https://cor.europa.eu/en/engage/studies/Documents/ division_of_powers/division_of_powers.pdf.

Ezcurra, Roberto, and Andrés Rodríguez-Pose. "Political Decentralization, Economic Growth and Regional Disparities in the OECD." Regional Studies 47, no. 3 (2012): 388-401. https://doi.org/10.108o/00343404.2012.731046.

Filippetti, Andrea, and Giovanni Cerulli. "Are Local Public Services Better Delivered in More Autonomous Regions? Evidence from European Regions Using a 
Dose-Response Approach." Papers in Regional Science 97, no. 3 (January 2017): 8o1826. https://doi.org/10.1111/pirs.12283.

Filippetti, Andrea and Sacchi, Agnese. "Decentralisation and Economic Growth Reconsidered: The Role of Regional Authority." Environment and Planning C: Government and Policy 34, no. 8 (2016): 1793-1824.

Finseraas, Henning, and Niklas Jakobsson. "Trust and Ethnic Fractionalization: The Importance of Religion as a Cross-Cutting Dimension." Kyklos 65, no.3(July 2012):32739. https://doi.org/10.1111/j.1467-6435.2012.00541.x.

Habyarimana, James, Macartan Humphreys, Daniel N. Posner and Jeremy M. Weinstein. "Why Does Ethnic Diversity Undermine Public Goods Provision?." American Political Science Review 101, no. 4 (2007): 709-725. https://doi.org/10.1017/ Sooo3055407070499.

Hooghe, Liesbet, Gary Marks and Arjan H. Schakel. "Operationalizing Regional Authority: A Coding Scheme for 42 Countries, 1950-2006." Regional and Federal Studies 18, no. 2-3 (2008): 123-142.

Kyriacou,AndreasP."EthnicSegregationand theQualityof Government:TheImportance of Regional Diversity." Constitutional Political Economy 23, no. 2 (2012): 166-180.

Kyriacou, Andreas P. "Ethnic Group Inequalities and Governance: Evidence from Developing Countries." Kyklos 6, no.1(2013): 78-101. https://doi.org/10.1111/kykl.12012. Marks, Gary, Liesbet Hooghe and Arjan H. Schakel. "Measuring Regional Authority." Regional and Federal Studies 18, no. 2-3 (2008): 111-121.

Marks, Gary, Liesbet Hooghe and Arjan H. Schakel. "Patterns of Regional Authority." Regional and Federal Studies 18, no. 2-3 (2008): 167-181.

Marschall, Melissa J., and Dietlind Stolle. "Race and the City: Neighborhood Context and the Development of Generalized Trust." Political Behavior 26, no. 2 (2004): 125-153.

Martinez-Vazquez, Jorge, Santiago Lago-Peñas and Agnese Sacchi. "The Impact of Fiscal Decentralization: A Survey." Journal of Economic Surveys 31, no. 4 (2016): 10951129. https://doi.org/10.1111/joes.12182.

Miguel, Edward, and Mary Kay Gugerty. "Ethnic Diversity, Social Sanctions, and Public Goods in Kenya." Journal of Public Economics 89, no. 11 (2005): 2325-2368. https:// doi.org/10.1016/j.jpubeco.2004.09.004.

Oates, Wallace E. Fiscal Federalism. New York: Harcourt Brace Jonanovitch, 1972.

Olson, Mancur. "Dictatorship, Democracy, and Development." American Political Science Review 87, no. 3 (1993): 567-576.

Ozgen, Ceren, Peter Nijkamp and Jacques Poot. "The Impact of Cultural Diversity on Firm Innovation: Evidence from Dutch Micro-Data." IZA Journal of Migration 2, no. 1 (2013): 1-18. https://doi.org/10.1186/2193-9039-2-18.

Ozgen, Ceren, Cornelius Peters, Annekatrin Niebuhr, Peter Nijkamp and Jacques Poot. "Does Cultural Diversity of Migrant Employees Affect Innovation?." International Migration Review 48, no. 1 (2014): 377-416. https://doi.org/10.1111/imre.12138. 
Quality of Government Institute of the University of Gothenborg. "Measuring the Quality of Government and Subnational Variation." Report for the European Commission Directorate-General Regional Policy Directorate Policy Development (December 2010): Page range. https://ec.europa.eu/regional_policy/sources/docgener/studies/pdf/2010_government_1.pdf.

Rodríguez-Pose, Andrés, and Roberto Ezcurra. "Is Fiscal Decentralization Harmful for Economic Growth? Evidence from the OECD Countries." Journal of Economic Geography 11, no. 4 (July 2011): 619-643. https://doi.org/10.1093/jeg/lbqo25.

Sacchi, Agnese, and Simone Salotti. "A Comprehensive Analysis of Expenditure Decentralization and of the Composition of Local Public Spending." Regional Studies 50, no. 1 (2014): 93-109. https://doi.org/10.1080/oo343404.2014.893387.

Stichnoth, Holger, and Karine van der Straeten. "Ethnic Diversity, Public Spending, and Individual Support for The Welfare State: A Review of the Empirical Literature." Journal of Economic Surveys 27, no. 2 (2013): 364-389. https://doi.org/10.1111/ j.1467-6419.2011.00711.x.

Stolle, Dietlind, Stuart Soroka and Richard Johnston. "When Does Diversity Erode Trust? Neighborhood Diversity, Interpersonal Trust and the Mediating Effect of Social Interactions." Political Studies 56, no. 1 (2008): 57-75.

Tanzi, Vito. "Pitfalls on the Road to Fiscal Decentralization." Working Papers, no. 19 (April 2001): 1-12. https://carnegieendowment.org/files/19Tanzi.pdf.

Tiebout, Charles M. "A Pure Theory of Local Expenditures." Journal of Political Economy 64, no. 5: 416-424.

Tselios, Vassilis, Philip McCann and Jouke van Dijk. "Understanding the Gap between Reality and Expectation: Local Social Engagement and Ethnic Concentration." Urban Studies 54, no. 11 (August 2017): 2592-2612. https://doi.org/10.1177/ oo4209801665०395. 